\title{
9. Religion and politics: The Christian churches and the 2006 coup in Fiji
}

\section{Lynda Newland}

On 5 December 2006, Commodore Bainimarama led a successful military coup against a Qarase government that had been strongly supported by the Assembly of Christian Churches of Fiji (ACCF), an umbrella organization in which the Methodist Church of Fiji is the most dominant member. Within two days of the coup, the Assistant General Secretary of the Methodist Church, in his capacity as chair of both the ACCF and a second umbrella group, the Fiji Council of Churches (FCC), condemned the coup as illegal and unconstitutional. This position has been retained - by the Methodist Church in particular, despite its support for the previous coups in 1987 and 2000. By contrast, the Roman Catholic Church took an alternative position, which was to become influential: That while the coup itself was illegal, the church supported the multicultural views expressed by the military and the interim government. Almost a year after the coup, in October 2007 and amid much controversy, head of the Roman Catholic Church in Fiji Archbishop Mataca accepted the role of co-chair of the National Council for Building a Better Fiji (NCBBF), the body charged by the interim government with developing the People's Charter for Change and Progress. Together with Commodore Bainimarama, he signed the draft charter in August 2008.

Clearly, the Christian churches played a role in the aftermath of the 2006 coup by articulating strongly divergent visions of the way that Fiji should be governed. This reflects the extent of the polarization between the Methodist Church and the Roman Catholic Church in Fiji (and consequently the division in and between Christian umbrella groups), and also shows markedly different ideas about the role religion should play in politics in Fiji.

\section{The umbrella groups: The FCC and the ACCF}

The FCC, an affiliate of the World Council of Churches, was established in 1964 as an ecumenical institution to unify Christians, deepen their faith, foster an understanding of other religious traditions and encourage activism in social justice issues. Its members are the Methodist, Anglican, Presbyterian and Samoan Congregational churches, the Roman Catholic Church, the Salvation Army and the Fiji Baptist Convention. Of these, the Methodist Church is the largest. It is also the largest religious organization in Fiji - with 36.3 per cent of the total population and 66.5 per cent of Fijians identifying themselves as Methodist in the 1996 Census. $^{1}$ 
By contrast, the ACCF was formed after the 2000 coup, and currently has about 27 member churches, para-churches and attached organizations. ${ }^{2}$ While the Methodist Church is central to the ACCF, nearly all the other churches and para-churches are Pentecostal and evangelical in orientation. Two influential members are the Assemblies of God and a fast-growing local variant of Pentecostalism, the Christian Mission Fellowship (CMF). Pentecostal/evangelical churches have burgeoned since the 1970s - with many of their converts drawn from the Methodist Church, which resulted in political and social upheavals within village communities. ${ }^{3}$ For the Methodists, an umbrella organization that promoted unity with the Pentecostal/evangelical churches offered a means by which Methodists could promote dialogue and teamwork - a measure which could go some way to healing divisions among Christian Fijians across Fiji.

The philosophy of the ACCF is not about ecumenism but about unifying Fijians under Christianity. In a country where the two main ethnicities are Fijian and Indo-Fijian (the latter are more likely to be Hindu, Muslim, or Sikh), most Christian churches have predominantly Fijian membership. ${ }^{4}$ The vision statement of the ACCF calls members to strive towards making Fiji a nation that honours and glorifies God in order that the country becomes 'God's Treasured Possession'. To attain that goal, all flocks need to unite, members should live God's way of love, leadership should be God-fearing, and Fiji should be reconciled for peace

and prosperity. ${ }^{5}$ As most Fijians are Christian and most Indo-Fijians are not, the vision statement's objectives are clearly aimed at uniting Fijians under (particular perspectives of) Christianity, and at converting all others - thus emphasizing the importance of Christian leadership in both church and government, and the importance of evangelism. With its underlying objective of turning Fiji into a Christian state, ${ }^{6}$ the ACCF's mission lies in stark contrast to the FCC's goals of promoting interfaith understanding and interaction.

While the FCC and the ACCF have profoundly different philosophies, the chair of both organizations is currently the Assistant General Secretary of the Methodist Church, Rev. Tuikilakila Waqairatu. The unfolding politics that have resulted from the stance of the various churches - particularly the Methodist and Roman Catholic churches - within the larger context of these umbrella organizations, are embedded in a history of active church involvement in politics; whether through direct influence on government or through critiquing government policy.

\section{The Fijian ethos, churches and politics before the 2006 coup}

The Methodist Church's notion of Fijian paramountcy lies in the history of the church in Fiji. As Wesleyan missionaries were the first to proselytize Christianity in the 1830s, and the first to convert powerful figures such as the Fijian high 
chief, Cakobau, Methodism became the most firmly rooted Christian belief system in Fiji. It was followed by the Roman Catholic Church, and, to a lesser extent, the Anglican, Presbyterian, and Seventh-Day Adventist churches; but Methodism remained dominant and became absorbed into the culture. ${ }^{7}$ To this day, the three pillars of Methodist Fijian social, political and cultural life are vanua (land and community), matanitu (the chiefly system), and lotu (religion, but in this context, Methodism). ${ }^{8}$

With the colonial project of mapping and recording the boundaries of native land, and with the arrival of the Indian indentured labourers for the sugar plantations, this basis of Fijian identity became more rigid and more politicized. Across Fiji, land was registered in the name of the kin-group of brothers called the mataqali, with patrilineal kin recorded in the Vola Ni Kawa Bula, the defining document for the Native Land Trust Board and the Ministry of Fijian Affairs 9 - effectively institutionalizing the land-owners or taukei in opposition to their tenants, the Indo-Fijians. As Fijians moved into urban areas, the Methodist Church increasingly became a centre for Fijians to discuss religious, social and political concerns, and provided the space for the emergence of ethno-religious nationalism, which surfaced in the lead-up to independence in $1970 .^{10}$ Lastly, the theology of salvation in Fijian Methodism is experienced in communal terms rather than individual terms, ${ }^{11}$ which translates relatively easily to a focus on the ethnic salvation of indigenous Fijians.

The sense of urgency for ethnic salvation was heightened with the increase in the Indo-Fijian population - especially from 1946 until 1986, when the Indo-Fijian population outnumbered the indigenous population of Fijians. ${ }^{12}$ At independence in 1970, racial identities were further rigidified along communal and racial lines in the new Fiji parliament. In 1987, when the Fiji Labour Party in coalition with the National Federation Party won the election, land ownership had been politicized to the extent that a Taukei (indigenous landowners) movement emerged, claiming that 'the Fijians appear to have lost their country'. ${ }^{13}$ Within a month of the swearing-in of the new government, Lieutenant Colonel Sitiveni Rabuka and 10-12 armed men marched into parliament and captured all government members, including the prime minister. ${ }^{14}$

A lay-preacher of the Methodist Church, Rabuka freely used religious imagery in his justifications of the coup. He was supported by the General Secretary of the Methodist Church, Manasa Lasaro, who influenced the military to impose the Sunday Decree, banning work on Sundays. When the interim government attempted to reinstate Sunday bus and taxi services at the end of 1988, Lasaro's followers set up roadblocks throughout Suva. ${ }^{15}$ These events led to a coup within the Methodist Church and the ousting of the Church's president, the Rev. Josateki Koroi - who had been critical of the coups - in favour of Rev. Isireli Caucau. ${ }^{16}$ 
Thirteen years later, in 2000, George Speight executed a third coup; this one was to remove Fiji's first elected Indo-Fijian prime minister, Mahendra Chaudhry, who had made a series of decisions that upset conservative Fijian interests. While Speight's interests in 2000 were expressed in a similar way to those of Rabuka in 1987, the churches' responses to this coup were not so clear. While a number of churches denounced the coup outright in advertisements posted in The Fiji Times and the Fiji Daily Post, the Methodist Church took several days to lodge a full-page advertisement stating that the Methodist Church in Fiji supported the interim government because Speight's objectives had been met. ${ }^{17}$ At the same time, it is alleged that the incoming president of the Methodist Church, Kanailagi, wrote to Speight and his colleagues to pledge the support of the Church. ${ }^{18}$ Meanwhile, Suliasi Kurulo, head of the CMF, wrote to Speight to demand the release of the hostages. A service involving 12 Pentecostal and evangelical churches and para-churches was held at the CMF's World Harvest Centre. Responding to Speight's request for a reconciliation meeting to be held at parliament, a group of pastors visited Speight and the hostages. ${ }^{19}$

As a direct result of the 2000 coup, the Assemblies of God leaders approached Rev. Tomasi Kanailagi, president of the Methodist Church, to call a meeting of all Christian churches in order to repair the political divisions between Fijians. Fourteen churches met and formed the ACCF, ignoring the existence of the FCC. Formed at about the same time as the political party, the Soqosoqo Duavata ni Lewenivanua (SDL), the ACCF became influential upon the SDL's rise to government, upon which it advised the government on significant issues and worked closely with the Ministry of Reconciliation. ${ }^{20}$ It supported the Qarase government's proposals to pass the Reconciliation, Tolerance, and Unity Bill and the Qoliqoli Bill (which concerned indigenous rights over reefs). Both of these bills promoted the interests of members in the indigenous Fijian community and had the potential to further marginalize Indo-Fijians. In addition, the Qoliqoli Bill was perceived to have the potential to create conflict between Fijian groups which had different interests in the reefs. The bills were key justifications for the military's overthrow of the Qarase government in a 'clean-up campaign'.

\section{The ACCF's response to the December 2006 coup}

In his immediate response to the coup, Rev. Tuikilakila Waqairatu condemned the takeover as illegal and unconstitutional, saying:

We are now deeply convinced that the move now taken by the commander and his advisors is the manifestation of darkness and evil, and we humbly appeal to them to reconsider their present course and remain loyal to the divine rule of God which will bring order and peace to the nation. ${ }^{21}$ 
He was supported by Sepesa Niumataiwalu, a pastor for the Church of God (another ACCF member church), who argued:

Christian churches in Fiji represent 52 per cent of the population and we oppose the formation of any interim government other than that of the elected government of Laisenia Qarase ...

We the church leaders represent a higher authority, and we offer spiritual support to the democratically elected government, this move by the military is the work of evil ...22

The strongest condemnation of the coup came from Suliasi Kurulo, head of the CMF, who, unlike the leaders of the Methodist Church, had also criticized the 2000 coup. In 2006, immediately after the coup, the CMF placed large advertisements in The Fiji Times and the Fiji Sun that appealed to all adherents of $\mathrm{CMF}$ - as well as to leaders and politicians - to uphold the law, and condemned the coup as 'unbiblical, ungodly, unconstitutional, unlawful, and unethical' ${ }^{23}$

Kurulo's strongest words - describing Bainimarama's leadership as dictatorial and manipulative - were reported by the Fiji Daily Post. Voicing his opposition against the overthrowing of a democratically elected government, Kurulo said that, from the Church's perspective, the 'military's action is purely the manifestation of darkness and evil and it interferes with our reasonable conscience'. ${ }^{24}$ The same source reported the CMF as calling for the commander to admit that his actions were illegal and to give up and to return the soldiers to their barracks, with Kurulo saying, 'We are appealing to the commander to take courage as a real man and admit that what he has done is ungodly, unconstitutional and unlawful' - and, noting that the coup cycle must be broken because it was based on lies and deception, and that, 'the church will continue to pray for justice, righteousness, understanding and goodwill to prevail'. Showing strong parallels with Waqairatu's position, these quotes suggest that Kurulo and Waqairatu were in close contact through this period.

The connection between the Methodist Church and the CMF was also evident in the views expressed at a multi-denominational service held at the World Harvest Centre. The service was held to seek divine intervention and to "pray for the lives of those who were in the military and those who had been or will be affected by the military takeover' ${ }^{25}$ Participants included Assemblies of God and Methodist adherents, as well as ousted Prime Minister Qarase. Waqairatu is reported to have preached at length, labelling the coup a 'manifestation of darkness and evil', and outlining a plan 'to call for the reinstatement of the elected government, to refuse to recognise military rule, to consider Commodore Bainimarama's justification for the coup - that Mr Qarase was corrupt and he would stand down - unacceptable' ${ }^{26}$ 
Under the Qarase government, it was not unusual for the Methodist Church and the ACCF to be visible at political meetings, often leading prayers and blessing rallies. Methodist ministers also prayed before the swearing-in of ministers into the Qarase government. Members of the ACCF arranged to gather at the FMF Dome in Suva in order to bless it before the meeting of the Great Council of Chiefs (GCC) that was held there two weeks after the coup.

The Methodist presence provoked Commodore Bainimarama to draw a parallel between the meeting and the GCC meeting that had been held at the parliamentary complex after the 2000 coup. Bainimarama said that the blessing was an act 'which has never been done before in any past GCC meeting venue'. He intimated that the GCC was being manipulated by the Methodist Church and therefore would lose credibility, and reiterated his belief that the coup was essential in order to lift Fiji 'out of the corrupt web that is so entangling [it], and propel Fiji towards a peaceful, prosperous and harmonious future'. ${ }^{27} \mathrm{He}$ was also reported as showing concern that Qarase had been invited to the GCC meeting - which would mean Qarase travelling back to Suva from his 'exile' on his home island of Vanuabalavu despite the military's warnings that they would arrest him and take him into military custody if he did. ${ }^{28}$

Rev. Waqairatu responded via the media that the ACCF represented the body of Christ, which was a much bigger power than the military, and maintained that the ACCF's fight was against evil, which, 'the military is succumbing to' ${ }^{29}$ Affirming that his blessings were not intended to be a move against the military, Waqairatu advised that 'nothing should be imposed as it should come from within, voluntarily when someone realises his/her mistakes' ${ }^{30}$ The same source reported him as saying that this meant that the military needed to clean up 'their own mess' before they embarked on the clean-up campaign; that '[D]ifferent governments will come and go but only one will remain - the most powerful one of all, which is the Kingdom of God'; and, with regard to blessing the GCC meeting, as saying that it was a norm for invited church leaders to bless the meeting. The prayer meeting at the Centenary Church was simply to call those who wished to pray for the nation, as the ACCF worked closely with the Ministry of Reconciliation to unite people, promote love, create God-fearing leaders and promote reconciliation and peace.

While Waqairatu's comments may have indicated that the Methodist Church of Fiji would continue to oppose the coup, after the GCC met, the Methodist Church appeared to recant and to join the Great Council of Chiefs supporting the interim administration in order to move Fiji forward. ${ }^{31}$ Yet this appearance of compliance was soon shattered by reports of a 20-point statement denouncing the coup. While the statement never appeared in full in the media, its contents were widely reported. Titled 'Here We Stand', the statement argued that the commander's actions of deposing and reinstating the President, and of terminating the Qarase 
government and multiparty cabinet, as well as the dissolution of parliament would be questioned in any court of law. ${ }^{32}$ It continued:

These actions must be viewed as a dangerous precedent to the governance of this country ie. the use of military power to usurp the mandate of a democratically elected government. The takeover should be deplored as a treasonous act against the State. ${ }^{33}$

In the short term, the coup exacerbated poverty - evidenced to the Church by the growing number of people seeking the Church's assistance. However, the Church accepted the interim government because of the need to restore the nation to democratic normalcy quickly. The President and the GCC were called upon 'to stand up for the rule of law and Godly principles, including human rights, in this difficult period'. The statement contained a request that, in the interests of the nation and to give credibility to the interim government, the President be medically boarded or retired with dignity and respect. ${ }^{34}$ It argued that, since the takeover, every action of the military had been illegal. Commodore Bainimarama and his interim ministers were asked to resign so that a politically neutral group of prominent and respected people could be appointed to govern until fresh elections were held. The military was called upon to return to the barracks. The statement also argued that all affirmative action programs for indigenous Fijians should be retained. ${ }^{35}$

Bainimarama responded by sending soldiers to meet with the Methodist Church president, Rev. Laisiasa Ratabacaca - with the result that staff members were taken to the barracks for questioning. ${ }^{36}$ The staff members involved were later revealed to be the Church's legal adviser, former RFMF senior officer, Lieutenant Colonel Tevita Bukarau, ${ }^{37}$ and the senior administration officer, Patiliai Leqa. As the military entered the Methodist Church, they assaulted a newspaper photographer and took him to the Queen Elizabeth Barracks because he had taken pictures of soldiers without their permission. ${ }^{38}$ In the military's view, those involved in drafting the statement were 'politically motivated' and the Church should have addressed the issue of President Ratu Josefa's resignation with the GCC rather than with the media.

In the days that followed, it became clear that the president, the general secretary and the assistant general secretary of the Methodist Church, had all sighted and approved the statement before it was released to the media. However, it had not been signed, instead carrying the letterhead of the Methodist Church in Fiji. ${ }^{39}$ According to the same sources, Major Neumi Leweni described the anonymity of the author as 'very unchristian-like' and claimed that the press statement was not credible, and that 'it was common knowledge there were people using the church to air their views' in an attempt to discredit the President and the interim prime minister. Representatives from the Suva branch of the Fiji Labour Party 
were reported as calling on spokesperson Mr Iliesa Naivalu and on Rev. Waqairatu to resign if they desired to engage in politics.

While the two Church officials were released after three nights in military custody, their release came with a warning from land force commander Colonel Pita Driti, who told the media:

We have been informed on certain aspects regarding plans by some church leaders and others who are trying to downgrade the military and the interim government and we warn them not to test our patience. ${ }^{40}$

In a press conference, Bainimarama warned the Methodist leaders against inciting people, saying that some of the Church leaders were manipulating events for their own benefit. Bainimarama was reported elsewhere as warning that the statement threatened the RFMF, that any threat to the military would not be taken lightly and, moreover, that the statement was written by a 'few misled talatala' (church pastors), and therefore did not show the Church's collective view. He was further quoted as saying that: 'They should not start something they can't finish'. 41

The 20-point statement was held over for the consideration of the Methodist Church's standing committee. The Church leaders resolved that only the Church president could release information to the media. At this stage, it was alleged that Tugaue, Naivalu, Waqairatu, Lasaro, and Bukarau had co-authored the document. ${ }^{42}$ However, while the Church's social services department, headed by Lasaro, had prepared the statement, it was claimed that Church executives had only looked at the paper for a few minutes before it became public and was released prematurely. 43

The military then met with a Church delegation that included Ratabacaca, Lasaro, Waqairatu and other senior ministers. The meeting lasted at least two and a half hours and, according to Major Leweni, was very successful. From Ratabacaca's perspective, while there were issues on which the two parties agreed to differ, they would continue in dialogue in the coming weeks. He argued that the Church was simply undertaking its prophetic and pastoral role in society, and reaffirmed its stance as raised in the statement, including with regard to the resignation of both President Iloilo and interim Prime Minister Bainimarama. ${ }^{44}$

In the same period, and after President Iloilo had addressed the nation, Rev. Kurulo of the CMF again spoke bluntly to reporters. Kurulo described the President's address as shocking and contradictory, saying that he was 'a puppet of the military'. It 'made a mockery of our culture, government and our beloved nation Fiji' and has left the country reeling. He said that it was a crying shame that the President stated he would have done the same things, that the commander's actions were legal, and that he continues to uphold the constitution. ${ }^{45}$ This appears to have been Kurulo's last statement to the media. 
Several months later, the interim government proposed the People's Charter for Change and Progress in order to forestall 'any further deterioration of Fiji's precarious overall economic and fiscal situation', to reform and restructure the economy, and to create a stable, transparent and accountable government under leaders who emphasize national unity and racial harmony. Originally, 120 organizations were approached for submissions on the charter, but, by the initial deadline, only 51 had responded, with just two or three submissions opposing it (which included the Methodist Church and the Naitasiri Provincial Council). The deadline was extended and, by 31 August 2007, from the 191 submissions hoped for, 95 responses had been received, with 82 supporting the proposal.

The Methodist Church's submission, signed by Ratabacaca, voiced opposition to the objectives of the Charter, pointing out that the nation should return to civilian rule at the earliest opportunity. It strongly stated that setting up the National Council for Building a Better Fiji (NCBBF) to develop the Charter would be unconstitutional, and that an interim government (and the military) should not be involved in such wide-sweeping structural change because they did not have the mandate of the people. In the Church's view, the previous government, which represented a mandate of the people, was excluded and, moreover, the interim government had decided to proceed with its plans before submissions were received. Furthermore, the Church objected to the removal of institutions directly supporting Fijians (such as the GCC and the Fijian Affairs Board), and to the increasing militarization and politization of the civil service. Lastly, the submission argued, some of the people appointed to positions of influence were not neutral or credible. In particular, there was concern over the appointment of Dr Sahu Khan as Chair of the Electoral Commission, given his record for 'questioning the legal basis of Fijian ownership of land'. ${ }^{46}$

The Commodore's response was that the leaders of the Methodist Church were 'deliberately misleading their followers to accomplish their own political agenda'. He singled out Rev. Waqairatu, who had been giving interviews to the media on the Charter, as 'trying to whip up Fijian emotions', specifically on the issue of land - the rights and ownership of which were not under question. ${ }^{47}$

After a period of silence between the military and the Methodist Church, Bainimarama was interviewed by the Australian media; he was reported as accusing 'the Methodist Church of sowing seeds of racial hatred' ${ }^{48}$, arguing that it was conspiring with the chiefs and politicians against ordinary Fijians and that the provincial councils and local lay-pastors in the villages and rural areas decide who ordinary Fijians should vote for. The same source reported a spokesman from a chiefly clan as responding by saying that this perspective ignored 'how the Almighty God put leaders in place to lead the vanua', and that those who spoke in the way that Bainimarama did do not know the protocol. Clearly, Bainimarama views the Methodist Church and the ACCF as not merely 
opposing him but as the greatest threat to his vision for Fiji. Yet, while the military has actively suppressed the ACCF, the Roman Catholic Church has been highly visible and active in promoting a vision of Fiji more in keeping with that of the military.

\section{A Catholic coup?}

While the Roman Catholic Church in Fiji condemned the coup, some of the statements of Archbishop Mataca and of activists like Father Kevin Barr of the Ecumenical Centre for Research, Education, and Advocacy (ECREA) have been perceived as supportive. And while Bainimarama was born a Methodist, he received a Catholic education. As a result, there have been questions over the extent of Catholic support for the coup.

As early as 19 December 2006, Father Barr and two co-writers, Paulo Baleinakorodawa and Semiti Qalowasa, published an article in The Fiji Times arguing that the coup was indeed illegal and wrong, but that, from the perspective of social justice, the Qarase government was guilty of manipulating democracy to serve Fijian nationalism. This, they said, was evidenced by the affirmative action initiatives, the Promotion of Reconciliation, Tolerance, and Unity Bill, the Qoliqoli Bill, and the Indigenous Lands Claim Bill. In addition, the Qarase government had ignored the poor and low-income workers and increased value added tax from 10 to 15 per cent. The fact that the military responded to this issue made it a coup 'in the name of multiculturalism'. Further:

It seems regrettable that those who have condemned the military takeover seem obsessed with the 'violation of democracy' perspective and fail to recognise the 'anti-racist' and 'pro-people' aspects of the takeover which could be termed the 'social justice' perspective. ${ }^{49}$

The article went on to claim that overseas governments that condemned the coup (the US, UK, and the EU) had forgotten their own wars, revolutions, and coups; and that, in Fiji, there are questions about the nature of democracy due to cultural practices, where Fijians vote according to the advice of their chief, provincial council or church minister. ${ }^{50}$ For some, according to these writers, it was not really a coup because of the protracted nature of events, and the Qarase government was not predisposed to listening. It was also, they alleged, peaceful, although 'some human rights violations may definitely need to be investigated'. At this point, the article changed direction, providing a very long list of changes that it hoped the military could achieve, stressing the possibilities of a multicultural and socially just society, and resonating with the sympathies many had for Bainimarama's position before the threat of a coup became serious. The writers reflected that, '[I]f these things come to pass we will have put our Christianity into practice and establish a nation where there is justice, compassion and inclusiveness'. 
When I interviewed Father Kevin Barr nine months later, he referred to this article, saying, 'we sort of said that [the ACCF's reaction to the coup] was to be expected in view of the collusion that existed between the Qarase government and the Assembly of Christian Churches in Fiji'. He went on to discuss the ACCF's activities in blessing the land in relation to:

... driving out the forces of darkness which were the gods of other peoples ... So there's a whole background there of racism, collusion and justification of Fijian nationalism by some of the Christian churches and so it was almost inevitable that, when the Qarase government was [ousted], the ACCF and those who represented ACCF would come out strongly and say these were the forces of darkness.

Re-affirming that the coup was illegal and that he was against any violations of human rights, Father Barr felt it was time to ask whether or not there were grounds that justified the ousting of a democratically elected government. For him, there were, given that the Qarase government was, in his view, very racist, represented a small section of the community, and colluded with the fundamentalist elements of the Methodist Church and the ACCF.

Similarly, Archbishop Mataca condemned the illegal overthrow of the Qarase government, noting that lessons had not been learnt from the coup in 2000. However, he was equally critical of the ACCF statement in that it did not call for a rapid return to democracy and the rule of law, or for the military acting with justice, but, rather hypocritically, labelled the commander and his advisors 'manifestations of darkness of evil', when they did not label the coup-makers of 2000 in the same way. ${ }^{51}$ Yet, Archbishop Mataca has also been critical of New Zealand's stance, arguing that it took hundreds of years for developed countries to find a democratic system of governance 'that they feel comfortable with' $^{52}$ Likewise, he has argued that the interim government should be accepted as it will return democracy. ${ }^{53}$

The most controversial move on the part of the Roman Catholic Church was Archbishop Mataca's acceptance to co-chair, with Bainimarama, the council for the People's Charter for Change and Progress, which was announced on 10 October 2007 by President Ratu Josefa Iloilo. According to the Vicar-General of the Catholic Church's council of priests, Father Kaloudou, the Charter 'was formulated by civil societies, not by the interim administration' ${ }^{54}$ and Archbishop Mataca was approached by 'a group of businessmen, academics, church leaders, civil society organisations and individuals'. Further, he 'only agreed to the appointment out of fear that the 1997 Constitution would be abrogated' and that if he allowed this to happen it would take the country back to the dark ages. ${ }^{55}$ 
The Archbishop's supporters include at least part of the FCC, with Rev. Isereli Kacimaiwai, seeing it as a window of opportunity that would aid the nation in moving forward. Bishop of the Anglican Church Apimeleki Qiliho has vocalized his support of the Archbishop's involvement, arguing that Mataca had been consistent since 1987 in his respect of other religions, cultures and faiths, and that he was 'a man of principle who would always stand for what he believed in and not be influenced by outside sources' ${ }^{56}$ Former politician Fred Caine has also come out in support, saying that the "silent majority of Catholics supported the Archbishop and the interim government 'to the hilt" in returning to democracy. ${ }^{57}$ For him, the position had nothing to do with politics. ${ }^{58}$

Mataca's detractors include Ro Teimumu Kepa, ousted education minister and Rewa paramount chief, who believes the Archbishop has wronged the Church because the position of co-chair is a political one and therefore undermines his neutrality, and that he will lose the trust of many Catholics. ${ }^{59}$ Former labour minister Kenneth Zinck, was part of a group, including Ro Teimumu Kepa and Tui Namosi Ratu Suliano Matanitobua, that approached the Archbishop to withdraw from the council because they feared his position would compromise 'the integrity and independence of the Roman Catholic Church' ${ }^{60}$ However, the meeting did not put to rest Zinck's concerns as he argued that 'He [the Archbishop] has joined a coup leader. That's worse than joining a political party'. ${ }^{61}$ Fred Caine condemned the meeting, saying it was presumptuous and arrogant. $^{62}$

Friar Kieran Maloney has been particularly critical, reportedly saying that the Archbishop's acceptance of the co-chair position is 'disgusting but not surprising' and that the Archbishop's involvement 'is giving credence to an immoral regime'. He likened the Archbishop's position to that of indigenous Catholic politicians whom he saw as racist, with views very similar to the views of the SDL, and opined that the views the Archbishop and Father Barr had published were 'very pitiful and despicable'. ${ }^{63}$

Lastly, the Catholic League wrote to the Vatican and the Apostolic Nuncio in Wellington. The league's president, Kepeli Lesi, argued that the Archbishop could not accept the position of co-chair because of a code in the Canon Law prohibiting priests from involvement in public office and politics, and claimed that 'the silent majority of Catholics feared a backlash from the military if they spoke out against Archbishop Mataca's decision' ${ }^{64}$ The Fiji Times then printed stories over four days (28-31 October), conveying little more than that Charles Balvo, the Archbishop in Wellington and representative of the Pacific to the Vatican, was waiting for more information from Archbishop Mataca. Finally, Archbishop Balvo responded that an archbishop had chaired a national conference in Berlin to help chart a new course, which was not deemed wrong because it was not considered to be running for office. ${ }^{65}$ 
The Archbishop's opposition within his own Church led him to make a public apology to those who felt he has wronged due to his acceptance of the position of co-chair, arguing 'I have not joined any political party. I joined the action group to build a better Fiji for all'. ${ }^{66} \mathrm{He}$ argued that all the coups had the aim of bettering the lives of Fijians but instead they 'brought more fragmentation, hurt, and poverty'. These views have been condemned by the ACCF, with ACCF General Secretary Sani Matalomani arguing that the 'removal of an elected government is against God', that the Archbishop needed to practice supportive speech, that he had become critical and bitter, and that he 'needs to allow the spirit of God to instil the love of God in him' ${ }^{67}$

\section{The relationship between religion and politics in Fiji}

Clearly, the media agitation regarding the divergent views of both Catholic and non-Catholic laity has shown the deep concern about the relationship between religion and politics in Fiji, but this concern is also present in Methodist adherents. While the Methodist Church was actively involved in the 1987 coups and has been a vocal commentator and support for the Qarase government since, not all its laity believe that this is a role for the Methodist Church. Indeed, outside of Suva, some have expressed concern about the extent to which the Methodist Church in Suva is involved with political issues that are not immediately relevant to rural areas. 68

With regard to the Catholic Church in Fiji, many see the Archbishop's acceptance of the co-chair role on the council for the Charter as profoundly political, given that the Charter was initiated by the interim government and that the Archbishop is co-chairing the council with Bainimarama. On the other hand, the Archbishop's position has always been that he wants to see Fiji progress towards a better future and that his position on a council is not the same as joining or endorsing a particular political party. Father Barr supports this position, arguing that there is a right and a wrong way for churches to be involved in politics:

I think the wrong sense is to be giving your support to the political parties, and endorsing and so on. I think the right sense is that the church has the right and the obligation to be critical of government policies and government actions, particularly when they impinge upon underprivileged and poor people. ${ }^{69}$

Thus, the dominant view in the Catholic Church of Fiji is that the church must be political in that it must relate to the issues of the day, but should not be endorsing particular parties. Yet the Catholic Church hierarchy's support for many of the views of the Bainimarama-led interim government suggests that this is not at all an easy position to take.

An example of this was Mataca's comment that, 'There are those who want elections to be held imminently, so that we can return to democracy as soon as 
possible, but elections alone will not bring about democracy nor guarantee stability or end all coups ${ }^{\prime}{ }^{70}$ In the context of no commitments having been met with regard to the proposed general election in March 2009 - despite strong regional and international pressure to hold elections as soon as possible; and because Mataca made these comments at the first meeting of the NCBBF - such statements are easily construed as being in favour of one political party over another. This conclusion is further strengthened by the fact that the riposte published the next day in The Fiji Times came directly from the SDL's director.

To complicate matters further, the Roman Catholic Church's theology in Fiji is based upon liberation theology. ${ }^{71}$ This theology maintains that oppressive social systems create social injustice and therefore must be actively challenged, sometimes with justifiable acts of 'counter-violence.' Father Barr expressed similar sentiments to me, drawing on Thomas Jefferson, who argued that the highest duty of a good citizen is to save the country when it is in danger, over and above strict observance of written law. In a second example, he drew on a statement by France's new minister of foreign affairs, who said that it was sometimes necessary to go outside the law to achieve justice. He related this back to the first article he and others wrote after the coup, saying:

We were talking about social justice, trying to do away with racism, have a multi-racial country where the benefits of development are for everybody and also make sure that human rights are observed. But you know, I spoke to one of the lawyers here in Fiji and I said, 'What do you think of that statement as a lawyer? Is it sometimes necessary to go outside the law to achieve justice?' And he thought for a moment he said, 'It's absolutely correct' ${ }^{\prime}$ '

Thus, while he views the military takeover as technically illegal, Father Barr strongly feels that, in this case, the end justifies the means. Given the strength of his views, it is not surprising that many have assumed Father Barr supported the coup outright.

Another level of analysis concerns the question of the relationship between religion and the state in Fiji. The Methodist Church and the ACCF have periodically called for a Christian state which, in the context of Fiji's divisions between the 'races' of Fijians and Indians, would legitimate and maintain the paramountcy of Christian Fijians as hosts, while all other races retain guest-status. By contrast the Roman Catholic Church, the Anglican Church, and the Presbyterian Church, which endorse ecumenism and tolerance, strongly oppose such a racially based paradigm.

However, the Archbishop's involvement in the Charter has suggested to at least one critic that the Roman Catholic Church might well sanction another kind of 
Christian state. This critic makes the point that, being a representative of the Roman Catholic Church, the Archbishop will be required to oversee:

... a process whose outcomes must be consistent with Christian values, beliefs and doctrines. While he may not actively impose his own personal views on the process, as a Christian, he would, presumably, have to sanction its outcomes in terms of his church's beliefs and only an outcome that accorded with those beliefs would be tolerated and accord with his conscience. $^{73}$

The writer gave homosexual marriage and abortion as examples to show that the Archbishop was unlikely to support any principle emerging from the Charter that was not fully consistent with those endorsed by the Vatican. Therefore, while the outcome would not be the same as that proposed by the Methodists, Roman Catholic values would be implicit in the outcomes of the Charter, which is to act as a guideline (and perhaps instrument) for selecting future governments. If this is the case, while the Archbishop's role is not directly political in that he has not technically joined any political party nor endorsed the coup, it will have political ramifications. ${ }^{74}$

\section{The FCC and ACCF revisited}

I have approached a number of religious leaders about the $\mathrm{ACCF}^{\prime}$ s responses to the coups, but many have responded they do not feel they can talk to me in the current political environment. ${ }^{75}$ However, there were some indications from the Assemblies of God that they were not entirely in agreement with some of the statements of the ACCF.

Rev. Tuikilakila Waqairatu's position as chair of both the ACCF and the FCC has, however, created considerable tension between FCC members - particularly, it would seem, between the Methodist Church and the Roman Catholic Church. Father Barr said:

I think an unfortunate situation is the whole takeover of the FCC by the Methodist Church and the ACCF. They've got a very strong representation there and I'm not a member of the committee there but I've heard from others that there's been a very strong move to change the FCC, to initiate changes in the constitution and even to do up a sort of a statement of beliefs that all churches [adhere to]. ${ }^{76}$

Within the FCC, churches are apparently expected to conform to the decisions made by Rev. Waqairatu, unless they express a different view as an individual church. In fact, the FCC is now divided to the point that they met only once in 2007, at their AGM (pers. comm., church member, 2007). As a result, there has been no public statement from the FCC regarding the People's Charter. 


\section{Conclusion}

During 2006 and 2007, the rhetoric of the churches threw up a number of ironies. On the one hand, while Rev. Waqairatu was representing both the FCC and the ACCF in his initial statement against the coup, his description of the military actions as 'manifestations of darkness and evil' had more in common with Pentecostal and evangelical notions of the end of the world, a Manichean viewpoint that does not resonate well with the more liberal and practical perspective of the FCC. On the other hand, the ACCF and, particularly the Methodist Church, has radically changed its position on the overthrow of democratically elected governments since 2000. Manasa Lasaro, a chief advocate of the 1987 coups, became visible again in 2006 as a co-writer of the 20-point statement put out by the Methodist Church and rejecting the coup as treasonous and illegal. Moreover, the 20-point statement appeared to be using the language of human rights, whereas, before the 2006 coup, Methodist leaders, and more broadly the ACCF, were often highly critical of human rights as a vehicle for foreign values, especially with regard to tolerating homosexuality.

If manifestations of evil had been the initial response of the ACCF, the Methodist Church's leader, Reverend Ratabacaca, issued a much less spiritually controversial statement in the form of the submission on the People's Charter. While it extends greetings in the name of Christ, and much later discusses Christian notions of justice, there is little to differentiate it in language from secular submissions of its sort. With the language of the Pentecostal churches no longer in evidence, the document is labelled as a submission by the Methodist Church and the ACCF and, in view of the fact that it is signed by the president of the Methodist Church, it would seem that the Methodist Church has come to increasingly act as the dominant party of the ACCF rather than simply a team-member. ${ }^{77}$

The land issue at the centre of the submission indicates a potential return to the concerns of 1987, where, despite the fact that land rights were entrenched in the constitution, fears about changes to land sparked off the Taukei Movement. While Commodore Bainimarama has refuted these claims, it is difficult to know at this stage what the extent of reform may entail, especially given that a Committee on Better Utilisation of Land was set up and that a report has already made recommendations to de-reserve native reserved land in sugar-growing areas. The latter has, however, since been rejected by the NLTB, a decision supported by the SDL. ${ }^{78}$

In response to such issues, the Methodist Church has set up a think tank, chaired by Manasa Lasaro, to discuss current political issues affecting the Church. SDL members are reported as participating. ${ }^{79}$ Given the close relationship between the SDL and the Methodist Church, this is not, in itself, surprising. Archbishop Mataca called for a meeting with the Methodist Church, which brought Qarase and Bainimarama together for discussions. ${ }^{80}$ However, this has not resulted in 
any breakthrough as the Methodist Church has continued to voice its opposition to the Charter ${ }^{81}$ and the police have continued to monitor Methodist activities, including the conference, to ensure that the Methodist Church is not used as a political forum. ${ }^{82}$

The Roman Catholic Church's leaders have shown more tolerance of the coup because it provides opportunity for the government to radically change direction in its social, economic and political policies. Prior to the coup, the interests of the Roman Catholic Church lay outside the interests of the Qarase government and in opposition to the influential ACCF. Despite the fact that the coup may have caused poverty, there was deep resentment of the Qarase government over policies that focused on Fijian paramountcy at the expense of poverty across racial boundaries, an emphasis that was particularly marked in proposed bills such as the Promotion of Reconciliation, Tolerance, and Unity Bill and the Qoliqoli Bill. There was also suspicion of the extent to which corruption prevailed: Hence Bainimarama's naming of the coup a 'clean-up campaign'.

In analysing the Roman Catholic position, there are also ironies. With a theology strongly rooted in seeking to improve the position of the poor, Roman Catholic leaders have underplayed the alleged human rights abuses at the Queen Elizabeth Barracks.

Moreover, the Archbishop's acceptance of the co-chair position on the NCBBF alongside Bainimarama created much controversy in the Catholic Church. The Archbishop argues that his acceptance may help prevent the abrogation of the constitution and ensure that racism is no longer on the agenda - thus, for many, the Archbishop's role is a step towards reconciling Fiji society. Yet, for others - within and outside the Catholic Church - it is an active engagement in the political realm that legitimates the coup.

It is clear that the military's relationship with the churches has profoundly changed since the 1987 and 2000 coups and is now one of opposition to ACCF interests - in which Methodist interests feature strongly. Ethno-religious nationalism of the kind that has, in past coups, been associated with the Methodist Church is currently repressed by the military, but remains one of the big threats to stability.

Lastly, the ACCF had striven to unify Fijians under the umbrella of Christianity, but clearly this has not been achieved. Instead, ACCF interests have been overthrown by a Fijian military that viewed the Qarase government's proposed bills as likely to return Fiji to its 'cannibal past' ${ }^{83}$ Both the ACCF and the military under Commodore Bainimarama believe they have answers that will lead Fiji to unity and prosperity, and that the alternative will lead to fragmentation between Fijians. Yet, their answers are polar opposites of each other - and at the nation's expense. 


\section{ENDNOTES}

${ }^{1}$ Fiji Islands Bureau of Statistics. 1996. http://www.spc.int/prism/fjtest/index.htm, accessed 23/5/07.The 2007 Census statistics are not yet available but are likely to show considerable change in church affiliation, away from the Methodist Church and towards the Pentecostal/evangelical churches.

2 In 2005, members were listed as: the Apostles Gospel Outreach Fellowship International (AGOFI); Assemblies of God, Fiji (AOG); Christian Mission Fellowship (CMF); Christian Outreach Centre (COC); Church of God of Fiji (COG); Covenant Evangelical Church (CEC); Grace Baptist Church; Advanced Breakthrough Ministry (ABC); Jesus Power Church; the Methodist Church in Fiji and Rotuma; the Methodist Davuilevu Theological College; New Life Centre; Pentecostal Churches of Fiji; Rescue Mission Fellowship; the Redeemed Christian Church of God (RCCG), the Worldwide Church of God in Fiji and Tonga; the Fiji Brethren Assemblies Partnership (Gospel Churches); the Family Life Ministry; the New Methodist Church; Fiji Baptist Convention; the Prison Chaplaincy; Impact World Tour/YWAM; Prison Fellowship; Global Sports Ministries; Summit Ministries (World Views); Teach us to Pray (ministry); and Assemble Communication.

3 Newland, L. 2004. 'Turning the Spirits into Witchcraft: Pentecostalism in Fijian Villages', Oceania, 75(1):1-18.

4 Indo-Fijians have joined the Indian Division of the Methodist Church, the Assemblies of God, and a small number of other Christian churches such as the Anglican Church and the Fijian Brethren Assemblies Partnership. Other small churches have mixed congregations of Pacific Islanders and whites (eg. the Presbyterian Church and the New Life Centre).

${ }^{5}$ Newland, L. 2006. 'Fiji' in Manfred Ernst (ed.) 2006. Globalization and the Re-Shaping of Christianity in the Pacific Islands, The Pacific Theological College, Suva.

6 A reference to the Christian state reappeared in March 2006 in an ACCF project aimed at healing the land; it then became a call to make each province in Fiji, Christian. See, Newland, L. 2007. 'The Role of the Assembly of Christian Churches in Fiji (ACCF) in the 2006 Elections' in Fraenkel, J. and Firth, S. (eds) 2007. From Election to Coup in Fiji: The 2006 campaign and its aftermath, Institute of Pacific Studies, Suva and Asia Pacific Press, Canberra.

7 Ernst, M. 1994. Winds of Change: Rapidly Growing Religious Groups in the Pacific Islands, Pacific Conference of Churches, Suva; Halapua, W. 2003. Tradition, Lotu, and Militarism in Fiji, Fiji Institute of Applied Studies, Nadi.

8 Niukula, Paula n.d. (circa 1994) The Three Pillars: The Triple Aspect of Fijian Society, Christian Writing Project, Suva.

9 France, P. 1969. The Charter of the Land: Custom and Colonization in Fiji, Oxford University Press, Melbourne; Clammer, J. 'Colonialism and the Perception of Tradition in Fiji', in Asad, T (ed.) 1973. Anthropology and the Colonial Encounter, Ithaca Press, London.

10 Halapua, W. 2003. Tradition, Lotu, and Militarism in Fiji; Norton, R. 1990. Race and Politics in Fiji, 2nd ed., University of Queensland Press, St Lucia, Queensland.

11 Bush, J. E. 2001. 'Land and Communal Faith: Methodist Belief and Ritual in Fiji', Studies in World Christianity: 21-37.

12 Tavola, H. 1991. Secondary Education in Fiji: A Key to the Future, IPS Publications, Suva; Chetty, N, K. and Prasad, S. 1993. Fiji's Emigration: An Examination of Contemporary Trends and Issues, Population Studies Programme, University of the South Pacific, Suva.

13 Norton, R. 1990. Race and Politics in Fiji, p.137.

14 Rabuka later justified this coup in terms of pre-empting bloodshed by Fijians attacking their own people (Halapua, W. 2003), which has resonances with some of Bainimarama's comments regarding the Qoliqoli Bill in 2006.

15 Halapua. W. 2003. Tradition, Lotu, and Militarism in Fiji; Ernst 1994, Globalization and the Re-Shaping of Christianity; Ratuva, S. 1999 Ethnic Politics, Communalism and Affirmative Action in Fiji: A Critical and Comparative Study, unpublished PhD Thesis, University of Sussex, England.

16 Rabuka also staged a second coup in 1987 when he was dissatisfied with the interim government's direction (Halapua, W. 2003).

17 Newland, L. 2006. 'Fiji' in Globalization and the Re-Shaping of Christianity.

18 Dakuvula, J. Pers. Comm. 2007.

19 Newland, L. 2006. 'Fiji' in Globalization and the Re-Shaping of Christianity. 
20 Newland, L. 2006. 'Fiji' in Globalization and the Re-Shaping of Christianity ; Newland, L. 2007. 'The Role of the Assembly of Christian Churches in Fiji (ACCF) in the 2006 Elections' in: Fraenkel, J. and Firth, S. (eds) 2007. From Election to Coup in Fiji: The 2006 campaign and its aftermath, Institute of Pacific Studies, Suva and Asia Pacific Press, Canberra..

21 Gurdayal, M., Devi, P. Tumoi, I., Pratibha, J., and Goundar, S. ‘Churches condemn Army's Interim Government', Fiji Daily Post website, 7 December 2006.

22 Gurdayal et al. 7 December 2006.

23 The Fiji Times, 6 December 2006, Fiji Sun, 6 December 2006.

24 Fiji Daily Post, 8 December 2006.

25 The Fiji Times, 11 December 2006.

26 Dominion Post, 11 December 2006.

27 Fiji Daily Post, 19 December 2006. Bainimarama appears to be referring to a rally at the Methodist Centenary Church that was to be held at the same time that the Great Council of Chiefs was sitting (Fiji One National News, 19 December 2006).

28 Fiji Daily Post, 19 December 2007. On the same day, The Fiji Times reported that the Prime Minister's Office had granted the ACCF $\$ 20,000$ from its small grant scheme to aid in establishing an office and purchasing equipment. This appears to be a decision made independently of Bainimarama's public jousting with the ACCF and the Methodist Church.

29 Fiji One National News, 19 December 2006.

30 Fiji Daily Post, 20 December 2006.

31 The Fiji Times, 10 January 2007.

32 fijilive, 2 February 2007; The Fiji Times, 3 February 2007; BBC Monitoring Asia Pacific, 4 February 2007; The Fiji Times, 7 February 2007.

33 fijilive, 2 February 2007; cf The Fiji Times, 3 February 2007.

34 fijilive, 2 February 2007; cf The Fiji Times, 3 February 2007. .

35 fijilive, 2 February 2007; The Fiji Times, 3 February 2007; BBC Monitoring Asia Pacific, 6 February 2007; fijilive, 6 February 2007; The Fiji Times, 7 February 2007.

36 The Fiji Times, 3 February 2007; BBC Monitoring Asia Pacific, 4 February 2007.

37 Bukarau was gaoled for offences related to the 2000 coup and released in 2006, so would have been of significant interest to Commodore Bainimarama (Dakuvula: Personal communication, 2007).

38 BBC Monitoring Asia Pacific, 6 February 2007.

39 The Fiji Times, 3 February 2007.

40 BBC Monitoring Asia Pacific, 5 February 2007.

41 The Fiji Times, 7 February 2007.

42 BBC Monitoring Asia Pacific, 6 February 2007.

43 BBC Monitoring Asia Pacific, 6 February 2007; fijilive, 6 February 2007. Some of the views in the daily papers were not especially supportive of the Methodist Church's position. For instance, an editorial in The Fiji Times criticized the release of the 20-point resolution, saying that, as a consequence of its early release, the Methodist Church had put itself in an embarrassing position and, because of its influence, the Methodist Church needed to exercise care and responsibility on important national issues. The views expressed in the document needed to be discussed with the interim administration, but the government also needed to work with the Church to resolve 'important national issues such as land, reconciliation, crime and poverty' and therefore to consult, not to confront (The Fiji Times, 7 February 2007).

44 BBC Monitoring Asia Pacific, 12 February 2007; The Fiji Times, 13 February 2007.

45 The Fiji Times, 4 and 5 January 2007.

46 Ratabacaca, Laisiasa 2007 Submission on Interim Government's "People's Charter for Change and Progress" Suva, June, at http://www.fijilive.com/news/show/news/2007/02/02/02Fijilive14.html

47 Curiously, however, the interim government then commissioned a report by Dr Krishnamurthy, which recommended that native reserved land in sugar areas should be de-reserved (Fiji Times 25/2/08). 48 The Fiji Times, 31 October 2007.

49 The Fiji Times, 19 December 2007.

50 This is an oft-cited practice but there is apparently evidence to the contrary (Dakuvula: Pers. comm. 2007). 


\section{The 2006 Military Takeover in Fiji}

51 Fiji Daily Post, 13 December 2006; The Fiji Times, 16 December 2006.

52 The Press (New Zealand), 24 January 2007. This kind of idea echoes some of the assumptions in Modernisation Theory, where all societies are expected to progress along the same path until they become developed. The idea of Fiji needing several hundred years to fully develop its fledgling democracy is commonly cited in Fiji.

53 For example, The Fiji Times, 10 January 2007.

54 How it was formed by civil society is unclear. It was certainly the interim government that launched the Charter and it was on Bainimarama's submission that the Cabinet endorsed it (Pacific Islands Report 2007; Interim Government 25 September 2007).

55 The Fiji Times, 27 October 2007.

56 Fiji Daily Post, 28 October 2007.

57 The Fiji Times, 29 October 2007.

58 Fiji Daily Post, 28 October 2007.

59 The Fiji Times, 24 and 25 October 2007. Rewa is one of the provinces that has rejected the Charter and the military takeover.

60 The Fiji Times, 24, 27 and 31 October 2007; Elbourne and Singh, 'Sorry: Mataca', The Fiji Times, 24 October 2007. There seems to be some confusion in the reporting of whether there was one or more meetings between Zinck and the Archbishop. There is also confusion in who attended as one report notes that Ro Teimumu apologised for 'lying about her presence at the meeting' (The Fiji Times, 27 October 2007) while a later report suggests that Teimumu did not go but that close friends of hers who were teachers had gone (The Fiji Times, 29 October 2007).

61 The Fiji Times, 27 October 2007.

62 The Fiji Times, 29 October 2007.

63 The Fiji Times, 25 October 2007.

64 The Fiji Times, 29, 30 October 2007; Fiji Daily Post, 31 October 2007.

65 The Fiji Times, 31 October 2007.

66 The Fiji Times, 24 October 2007.

67 The Fiji Times, 16 February 2008.

68 For instance, in focus groups I conducted in Labasa, Vanua Levu, in 2005, several Methodists were highly critical of the statements by the church in Suva. One railed against the position the Methodist Church in Suva had taken on homosexuality, liquor licences, and the Reconciliation, Tolerance and Unity Bill, arguing that the church should not be involved in politics at all. Newland, L. 2006. Social Justice in Fiji: Christian Perspectives, ECREA, Suva.

69 Interview, 19 September 2007.

70 The Fiji Times, 18 January 2008.

71 As many have noted, the Archbishop's views are similar in style to the views of Father Kevin Barr. I conducted research for ECREA, which was headed by Father Barr, in 2005. During this research period, I was asked to explore Liberation Theology as it developed through the Popes' Encyclicals and Catholic meetings, such as the Medellin Conference in Latin America, as part of a broader piece of research on social justice.

72 Interview, 19 September 2007.

73 Fiji Daily Post, 30 October 2007.

74 More recently, Archbishop Mataca appeared on the current affairs program, Close-Up, saying that the Charter was a Covenant, which suggests a more intense relationship between the state and the Roman Catholic Church than was otherwise being conveyed ('Close-Up', Fiji One, 13 April 2008). Curiously, when I asked to see the tape of the broadcast, it had mysteriously disappeared.

75 While I was attempting to do this research, another State of Emergency was put in place.

76 Interview, 19 September 2007.

77 The Methodist Church's public refusal to join the Charter has been contested, albeit mildly, from within the church. The church's Indian division prepared its own submission in support of the People's Charter, which it discussed with the Methodist hierarchy (The Fiji Times, 25 February 2008). However, the submission appears to have resulted in a strategic plan for a sole church (the Dudley Methodist Church). Using an analysis popular in business (the SWOT analysis which examines strengths, 
weaknesses, opportunities, and threats), the plan's aim is to make the church more service-oriented and re-focused on evangelism in the Indian communities (The Fiji Times, 17 March 2008).

78 The Fiji Times, 5 March 2008.

${ }^{79}$ Fiji One National News, 4 March 2008. Lasaro ran for president at the Methodist Conference but lost to Rev. Tugaue.

80 'Bainimarama and Qarase told to sort out differences' Fiji One National News, 20 May 2008.

81 'Methodist Church says it will not accept Draft Charter', Fiji One National News, August 17, 2008

82 The Fiji Times, 16 August 2008.

83 The Press, 4 November 2006. 